\title{
Countering Islamic Radicalism in Central Asia
}

\section{Rouben Azizian *}

\section{Introduction}

Radical Islamist groups make up the bulk if not all of the terrorist organizations presently found in Central Asia. Despite the loss of their bases in Afghanistan, terror groups in the region have adapted, and are mounting increasingly potent operations. New alliances have sprouted up as well. These groups and their message have produced an increase in discord between neighbors in the region, as some states blame others for cross-border terrorist activities, as when Uzbekistan accused Kyrgyzstan of harboring terrorist training grounds for those responsible for the Andijan uprising. ${ }^{1}$ According to Nurliman Abdulhasan, a professor at Tashkent Islamic University, there is a growing threat from Islamist extremism throughout Central Asia. These groups are increasingly diverse and are actively engaged in efforts "to initiate strong ties with religious extremist organizations abroad and to involve the latter in the training of militant groups and providing material and technical support for their activities.” Abdulhasan notes a lack of regional cooperation in combating these groups, and specifically criticizes Kyrgyzstan for "failing to take serious measures against religious extremist organizations."2

Poverty, rampant corruption of political elites, and a lack of political freedom have caused many in the Central Asian population to align themselves with terrorist groups, because they feel such groups offer them a better avenue to participate in the political process. As one young man was quoted saying in the Christian Science Monitor, "All we have got [from the post-Soviet secular order] is poverty, unemployment, strife, and immorality all around. People need to be brought up properly. If we had Islamic law here, we would have peace and order." ${ }^{3}$

In terms of locating the main geographic hotspots of religious extremism, in the past Uzbekistan and Tajikistan have traditionally been identified as the most problematic and explosive locales. The high level of Islamist radicalization among their populations, along with a repressive form of governance, was considered objectively conducive to extremist activity. On the other hand, Kazakhstan and Kyrgyzstan were seen as less problematic due to their societies' nomadic traditions, high degree of secularization, and better governance. Some experts consider Islamist radicalism in Kazakhstan

* Rouben Azizian is Professor at the Asia-Pacific Center for Security Studies in Honolulu, Hawaii. The views expressed in this chapter are his, and not those of the Asia-Pacific Center or the PfP Consortium.

1 “Uzbek Official Accuses Kyrgyzstan of Negligence Towards Extremists,” BBC Monitoring Newsfile (15 September 2005).

2 Interfax News Agency, 11 May 2006; summary available at www.hri.org/news/balkans/ rferl/2006/06-05-12.rferl.html\#20.

3 Fred Weir, “Islamic Gambit in Central Asia,” Christian Science Monitor (19 July 2006). 
and Kyrgyzstan to be an irritant rather a threat. According to Kazakh scholar Nurlan Alniyazov, however, strange as it may sound, in areas where Islam has been traditionally present, and where religion has a profound impact on the cultural, spiritual, and everyday life of a society, there is a natural resistance to radical movements, which are perceived by the people as something alien to their culture and traditions and unsubstantiated by traditional teachings of Islam. In contrast, fundamentalist groups are often able to flourish in areas where Islam has not put down deep roots. ${ }^{4}$ Islamist radicalism is on the rise in both Kyrgyzstan and Kazakhstan. If the challenge is not treated seriously and consistently, it may develop into a serious threat to the region and beyond. Destabilization in these countries would be a concern to a number of geopolitical players, but it would in particular seriously harm the strategic interests of the United States. After the withdrawal of U.S. troops from Uzbekistan, Kyrgyzstan became America's key military partner in Central Asia, despite the recent volatility in their bilateral relations. Kazakhstan, on the other hand, remains the strongest economic partner of the United States in Central Asia, and perhaps the most promising candidate for political liberalization.

\section{Islamist Radical Groups}

The Islamic Movement of Uzbekistan (IMU) and Hizb ut-Tahrir (HT) represent today the most serious threat to stability and democracy in Central Asia. The IMU and HT include various splinter groups and affiliations, reflecting struggles over ideological agendas and methods of activity within the broader Islamist movement. Despite claims by Central Asian governments of an alliance between HT and the IMU, there is no evidence that such cooperation exists. It is true that both groups advocate the establishment of an Islamic state, typically a restoration of the caliphate. Also, since Hizb utTahrir is the only Islamist group active in the region that has a coherent ideology, other Islamist groups, including the IMU, have relied on the comprehensive teachings of HT, which is currently the most popular radical movement in Central Asia. ${ }^{5}$ The main difference between the two groups is one of focus: the IMU openly advocates and carries out militant operations, while HT concentrates on the ideological battle. The two groups nonetheless admit the closeness of their goals, and both are propelled closer to the achievement of their ends by the weakness of Central Asian states.

\section{The Islamic Movement of Uzbekistan}

Although the activities of the Islamic Movement of Uzbekistan have been diminished after the U.S. invasion of Afghanistan in 2001, the group has by no means disappeared. The IMU is considered active in Kyrgyzstan, Uzbekistan, and Tajikistan, and has been

4 Nurlan Alniyazov, “The Muslim Board and Muslim Community in Kazakhstan,” in State and Religion in Countries with a Muslim Population, eds. Z. I. Munavvarov and R. J. Krumm (Bonn: Friedrich Ebert Stiftung, 2004), 175.

5 Zeyno Baran, S. Frederick Starr, and Svante E. Cornell, "Islamic Radicalism in Central Asia and the Caucasus: Implications for the EU,” Silk Road Paper, presented at the Central AsiaCaucasus Institute (Washington, D.C.: SAIS, July 2006), 18. 
blamed for attacks throughout these three states. There is, however, the issue of the veracity of official Uzbek, Kyrgyz, and Tajik reports of stepped-up IMU activity, which is somewhat less than absolute. This is a long-standing problem throughout the region, as Central Asian governments have a well-documented history of using the threat of extremism to justify politically motivated crackdowns, alleging militant activity without providing credible evidence, failing to conduct adequate investigations in the wake of violent incidents, and obtaining convictions with confessions extracted under highly dubious circumstances. These states' track record does not necessarily invalidate their official statements, but it does make it difficult to draw clear conclusions.

For example, Akramiya, a splinter group from the IMU (or HT, according to other sources), was blamed, along a few other extremist groups, for masterminding the events in Andijan in May 2005, in which Uzbek troops fired into a crowd of protesters who the Uzbek government claimed had been incited by radical Islamist groups, killing an unknown number of "terrorists" and sparking days of unrest. After the leader of Akramiya, Akram Yoldoshev, was captured, he admitted the group's involvement. However, due to the authorities' habit of using torture as a means to extract confessions, it is not clear how seriously this confession should be taken.

Reports of IMU activity in Kyrgyzstan and Tajikistan come at a time when relations between those two countries and Uzbekistan-where the government of President Islam Karimov has long been the ultimate target of the IMU—are heading in very different directions. While Kyrgyzstan has started to increasingly cooperate with Uzbekistan, the state of Tajik-Uzbek relations (which were never noted for their warmth) have recently taken a marked turn for the worse amid tit-for-tat spying allegations, and Tajik charges that Uzbekistan has allowed the operation within Uzbek territory of more than ten training camps for supporters of Colonel Mahmud Khudoiberdiev, who was behind a failed 1998 coup attempt in Tajikistan.

Against this domestic and regional backdrop, the current status of the IMU remains unclear. In February 2006, Radio Free Europe and Radio Liberty (RFE/RL) examined a range of answers to the question, "Is the Islamic Movement of Uzbekistan Really Back?” No consensus emerged among regional experts.

\section{Hizb ut-Tahrir}

Hizb ut-Tahrir, while not officially considered a terrorist group by the United States, is regarded as one in Central Asia. Having only been active in Central Asia since the 1990s, the group has spread to Russia, China, Tajikistan, Kyrgyzstan, Kazakhstan, and Uzbekistan. Although it is regarded as being most active in Kyrgyzstan and Uzbekistan, its influence in Tajikistan and Kazakhstan is increasing.

Representatives of Hizb ut-Tahrir say their activities are peaceful, and claim they do not engage in political violence; rather, they only instruct and convince Muslims of the need to establish a modern caliphate. But the governments of Uzbekistan, Tajikistan, Kyrgyzstan, Kazakhstan, and Russia regard HT as an extremist organization, and have banned its activities. Hundreds of accused Hizb ut-Tahrir members are now held in jails across Central Asia as "religious extremists" who pose a danger to law and order. The Uzbek authorities were also quick to accuse Hizb ut-Tahrir of involvement in 
the violence in Andijan in May 2005. But many human rights groups are not convinced that all those who have been arrested are guilty of trying to overthrow the state. They allege that the Uzbek government is cracking down on all forms of political dissent, and say that even peaceful Muslims practicing their faith outside state-controlled religious establishments risk persecution.

According to Michael Hall, Director of the International Crisis Group's (ICG) Central Asia Project, the lack of justice, accountability, and fairness in their political institutions is the main reason why many Central Asians are increasingly driven to join groups like HT and become susceptible to arguments suggesting that a caliphate, or global Muslim state, would provide this kind of accountability, justice, and fairness. ${ }^{6}$ Hizb ut-Tahrir member Badalov insists that government repression has increased the group's popularity. "The people have already seen the governments' slander against us," he said. "They understood that it is slander and provocation. The authorities can blame us, but the people already know very well that we won't do anything like [carrying out acts of violence]."7

Hizb ut-Tahrir, which says it abjures violence and only uses agitprop (agitationpropaganda) methods for propagating its ideology, focuses on penetrating the student community, the armed forces, and the security agencies. It has also managed to build up a large following among Muslim medium- and small-scale entrepreneurs. It advocates what it describes as "Islamic democracy," in which Allah and not the people will be sovereign, and an Islamic version of the free market economy, in which private entrepreneurs accept a moral responsibility for the welfare of their employees. Private enterprises are expected to serve the cause of religion and the community. Every member of HT is required to contribute ten percent of his or her earnings to the organization. Its other sources of funding are not known.

In view of its emphasis on propaganda, HT tries to invest in printing presses and publishing houses directly or through intermediaries. The group has not been identified as controlling any madrassas (seminaries) of its own. Rather, it recruits its student members from all educational institutions_religious or secular, public or private. It also advises its clerics to avoid attracting attention to themselves; they are discouraged from keeping long beards, and are even advised to dress in Western clothes. ${ }^{8}$

\section{Central Asian Counterterrorism Strategy}

Across Central Asia, governments are increasingly asserting their control over the religious establishment, and have begun banning groups that refuse to cooperate with the state. These governments are motivated by the fear that uncontrolled Islam could be a

6 Gulnoza Saidazimova, “Central Asia: Suppressing Hizb Ut-Tahrir Could Radicalize Youths,” RFE/RL (28 July 2006); available at http://www.eurasianet.org/departments/insight/ articles/pp072906.shtml.

7 Ibid.

8 B. Raman, “Islamic Blame Game,” Asia Times Online (17 May 2005); available at www.atimes.com/atimes/Central_Asia/GE17Ag03.html. 
potent force for political opposition. But, as regional governments try to crack down on groups like Hizb ut-Tahrir, there is no sign yet that the movements are disappearing. Some analysts caution that state efforts to control political Islam-including by arresting members of Islamic organizations that refuse to join the state-approved religious establishment - could eventually backfire. The other worrying sign is that, if a few years ago Uzbekistan's repressive policy toward Islamist and other opposition was regarded as excessive, other Central Asian states (including relatively democratic Kazakhstan and Kyrgyzstan) are resorting to force today in dealing with Islamist groups. All of these states, however, are doing much less to address the sources of Islamist radicalism than they are doing to suppress its organized manifestations. The following case studies of Kyrgyzstan and Kazakhstan indicate the increasingly aggressive approach taken by authorities in these states toward Muslim opposition groups.

\section{Kyrgyzstan}

Kyrgyzstan has long been a fertile ground for the growth of fundamentalist Islam. Since the breakup of the Soviet Union, it was Kyrgyzstan that adopted the most liberal approach toward Islamic fundamentalist organizations among the five Central Asian republics, allowing, for example, Hizb ut-Tahrir to pursue its activities relatively freely. At the same time, Kyrgyzstan's social and economic situation was deteriorating under the increasingly corrupt regime of Askar Akaev. Kyrgyzstan has common and poorly protected borders with Uzbekistan and Tajikistan, the two countries in the region that have experienced more serious Islamist radicalism. Finally, Kyrgyzstan has a significant Uighur population, which has radical anti-Chinese and/or pro-independence aspirations.

It is, however, Hizb ut-Tahrir that has become the main source of concern for the Kyrgyz authorities. Southern Kyrgyz regions_including Osh and Jalalabad, which have large numbers of ethnic Uzbek residents-have traditionally been strongholds of support for HT. Uzbeks make up 12.9 percent of the population of Kyrgyzstan, and 40 percent of the population of the Osh region. According to official figures, 92 percent of Hizb ut-Tahrir activists are ethnic Uzbeks. ${ }^{9}$ At the same time, HT propaganda material has been heavily distributed in cities in northern Kyrgyzstan, including the capital, and Kyrgyz law enforcement officials have reported a surge in HT leafleting. According to Sadykzhan Kamuluddin, President of the Islamic Center of the Republic of Kyrgyzstan and former mufti and member of the Kyrgyzstan Supreme Council, Kyrgyzstan alone has about two to three thousand members of Hizb ut-Tahrir, suggesting that HT is numerically strongest in Kyrgyzstan. ${ }^{10}$ Other sources estimate HT membership in Kyrgyzstan to be close to five thousand members. Officials of a Kyrgyz state commission

9 Alisher Khamidov, “Islamic Radical Group Intensifies Underground Activity in Kyrgyzstan,” Eurasia Insight (14 April 2003); available at www.eurasianet.org.

10 Igor Rotar, "Hizb ut-Tahrir Today," Terrorism Monitor 2:5 (11 March 2004); available at www.jamestown.org/publications_details.php?volume_id=400\&issue_id=2920\&article_id= 23608. 
for religious affairs admit that Hizb ut-Tahrir poses a significant "threat to national security."11

The Akaev government took several measures to control the spread of radical Islamist ideology. One was the adoption of a strict licensing system regulating the publication of religious printed matter, under the supervision of the Ulema Council, Kyrgyzstan's foremost spiritual body for Islamic affairs. The Kyrgyz State Commission for Religious Affairs passed a number of other regulations to govern religious expression and counter radical elements. In addition, the Supreme Court of the Kyrgyz Republic issued a ban on four Islamic groups. Henceforth the activity of these groups, which the court officially labeled as "terrorist and extremist," is considered illegal within the republic. These groups are Hizb ut-Tahrir, the Islamic Party of Turkestan, the East Turkestan Liberation Organization, and the East Turkestan Islamic Party. ${ }^{12}$

The March 2005 parliamentary elections in Kyrgyzstan once again brought Hizb ut-Tahrir under close scrutiny by the international community. HT's anti-government propaganda made some contribution to the public uprising against the Akaev government. At the same time, the HT leadership did not support the new government, as it does not differentiate between new leaders and former president Askar Akaev's administration. Hizb ut-Tahrir members view the events of March 2005 as simply a reshuffling of power, lacking any significant departure from the previous regime's policies. "We will support people and the government representatives only when they defend the interests of Islam. Disputes between the people and President Askar Akaev's government were part of a democratic ideology which is alien to Hizb ut-Tahrir," according to Dilyor, a HT activist in Kara-Suu. ${ }^{13}$

Kyrgyzstan's social and economic situation after the “Tulip Revolution” has shown no signs of improvement. The Kyrgyz government is starting to have serious concerns about domestic stability, and is resorting to harsher methods of dealing with Islamist groups as their influence is once again starting to grow. There has been increased counterterrorism cooperation between Kyrgyzstan and Uzbekistan as the Kyrgyz authorities have taken a harder line in fighting extremism, which would be in keeping with Tashkent's policies. Another sign of possible Uzbek influence on Kyrgyz counterterrorism efforts is the tendency to conflate Hizb ut-Tahrir with the IMU. This conflation has long been a staple of Uzbek official pronouncements, and has figured prominently in a number of trials in Uzbekistan.

\section{Kazakhstan}

Governmental leaders in Kazakhstan are starting to reluctantly admit the growth of religious extremist activity in the country. In the past, the Kazakh government dismissed the danger of Islamist extremism, and somewhat patronizingly suggested that Islamism

11 Kabar News Agency, 12 July 2005.

12 Interfax News Agency, 14 January 2004.

13 Alisher Khamidov and Alisher Saipov, "Islamic Radical Group Bides Time on the Sidelines of Kyrgyzstan's Revolution,” Eurasia Insight (14 April 2005); available at www.eurasianet.org/departments/insight/articles/eav041405.shtml. 
was present only in neighboring Central Asian states. They claimed that extremism was marginal in Kazakhstan, and was limited to Uzbek and other ethnic minorities, such as the Uighurs, Chechens, and Azerbaijanis, but was not present among ethnic Kazakhs.

The Chimkent region of southern Kazakhstan, which borders Uzbekistan, is regarded by the Kazakh authorities as the main breeding ground for religious extremism in the republic. Kazakh officials speak of the widespread presence of "Wahhabis," a term frequently deployed in Central Asia to describe both Islamist extremists and ordinary Muslims who simply worship outside state-controlled structures. The attention paid by the authorities to the Chimkent region in particular is easily explained-the overwhelming majority of the republic's 330,000 ethnic Uzbeks are concentrated in Chimkent, making up around 18 percent of its population. Generally, the Uzbeks are far more conservative and observant than the Kazakhs in their practice of Islam, and consequently the number of Islamist radicals among them is much greater. ${ }^{14}$

The terrorist group known as "Jamaat of Central Asian Mujahideen," which is structurally affiliated with Al Qaeda, has been exposed and dismantled in Kazakhstan. ${ }^{15}$ According to Kazakhstan's National Security Committee (KNB), the Jamaat was administered from abroad through appointed leaders, known as emirs. One of them, Akhmed Bekmurzayev, was killed during counterterrorist operations in Tashkent in March 2004. ${ }^{16}$

East Turkestan (Uighur) radical groups connected to Al Qaeda and Iraqi insurgent groups are present in Kazakhstan as well. The leadership of the Uighur community in Kazakhstan is generally unhappy with President Nazarbaev's policy towards the Uighurs, and accuses him of not caring about the plight of Uighurs in China. The government of Kazakhstan, hypersensitive to Chinese reactions, has always distanced itself from the East Turkestan problem and the plight of the Chinese Uighurs, despite the fact that the Kazakh government's decision to ignore the reprisals against ethnic minorities in China's Xinjiang Autonomous Region drew sharp criticism from Uighurs living in the Almaty region of Kazakhstan. ${ }^{17}$

According to Kazakh experts, there are four separatist organizations in Kazakhstan and Kyrgyzstan involved in anti-Chinese activities in Xinjiang. They are the Unified National Revolutionary Front of Eastern Turkestan; the Organization of Liberation of Uighurstan; the International Committee for Liberation of Eastern Turkestan; and Yana Ayat. The four groups differ regarding the tactics they use in their struggle, but they all

${ }^{14}$ Igor Rotar, “Kazakhstan: Is Chimkent a Hotbed of Islamic Radicalism?” Keston News Service (17 January 2002); available at www.assistnews.net/Stories/2002/s02010044.htm.

15 See Igor Rotar, "Demographics, Borders Complicate Anti-Terrorism Efforts in Central Asia," Eurasia Daily Monitor 1:130 (18 November 2004); available at http://jamestown.org/edm/ article.php?article_id=2368881.

16 Interfax-Kazakhstan News Agency, 11 November 2004.

17 Marat Yermukanov, "Astana Offers Clumsy Explanations for Banning 'Terrorist Organizations,'” Eurasia Daily Monitor 1:108 (18 October 2004); available at http://jamestown.org/ edm/article.php?article_id=2368710. 
basically seek a radical overthrow of the government in Xinjiang. ${ }^{18}$ However, Konstantin Syroezhkin, a prominent China scholar based in Almaty, believes that most of the Kazakh and Kyrgyz members of the radical groups in fact immigrated from China in recent years. They lack education, and do not belong to the Uighur elite. They are normally of older age, believe in the break-up of China, and count on Western support. ${ }^{19}$ Further radicalization of the Uighur movement in Central Asia is possible, however. There is a great degree of hostility against Uighurs in both Kazakhstan and Kyrgyzstan. Uighur intellectuals in Kazakhstan and Kyrgyzstan complain that constant attempts are made to label Uighurs as unpatriotic. According to such accounts, Uighurs are suspected of trying to create a Greater Uighurstan, which would include parts of Kazakhstan and Kyrgyzstan as well as China.

In October 2004, the Supreme Court of Kazakhstan recognized Al Qaeda, the East Turkestan Islamic Party, the Kurdish People's Congress, and the Islamic Movement of Uzbekistan (IMU) as terrorist groups, a decision that prohibits them from any activity in the country. The ban on activities of the East Turkestan Islamic Party and the Kurdish People's Congress was obviously aimed at demonstrating Kazakhstan's support for Chinese and Turkish anti-separatist efforts on the one hand, and the government's commitment to fighting international terrorism on the other.

It is, however, Hizb ut-Tahrir that is becoming particularly worrisome to the Kazakh government, as more and more HT cells are operating in the country. The group has now spread all over the country, and is no longer confined to the southern provinces. The number of Kazakh members of HT is on the rise as well. Most of the new members are attracted to HT for social and economic reasons. Kazakhstan's economic progress may be impressive, but it is uneven and inequitably distributed, and has in fact led to greater polarization in Kazakh society. In March 2005, the Astana City Court ruled to classify Hizb ut-Tahrir as an extremist organization and to ban it in Kazakhstan. $^{20}$

The lower house of the Kazakh parliament voted in May 2005 to adopt stricter antiterror legislation. The legislation, consisting of a set of amendments to eleven existing national security laws, imposes heavier penalties for "extremist and terrorist activities," including "terrorist financing," and introduces more restrictive measures governing the activities and formal registration of religious organizations and political parties. ${ }^{21}$

Kazakhstan has positioned itself as a staunch supporter of the West's war on terror. Kazakhstan is undoubtedly working to establish itself as a state actively cooperating in the war on terror, and is keen to promote an image of itself as being at the heart of Eurasian efforts to create a more stable environment, a perception that will clearly benefit domestic economic investment. But at the micro level, experts within Kazakh-

18 M. Laumulin, ed., Trends in the Evolution of Extremism in Central Asia (Almaty: Kazakhstan Institute for Strategic Studies, 2003), 61-63.

19 K.L. Syroezhkin, Myths and Realities of Ethnic Separatism in China and Security of Central Asia (Almaty: Daikh Press, 2003), 466.

20 Kazakhstan Today (29 March 2005).

${ }^{21}$ ITAR-TASS News Agency, 12 May 2005. 
stan are beginning to question the state's anti-terrorist agenda, and diverge in their views on what shape it will take in the future. ${ }^{22}$

Like Kyrgyzstan, Kazakhstan has warmed to the Uzbek approach to dealing with Islamist groups. Despite traditional tensions between the two states, and the regional rivalry between Almaty and Tashkent, the level of security cooperation between the two countries has been steadily growing. After an initially cautious reaction to the Uzbek crackdown in Andijan in May 2005, the Kazakh government has responded more favorably to the Uzbek interpretation of the events in Andijan, and to Uzbekistan's hard-line policy in general.

\section{External Partners}

The Central Asian nations' balancing-act approach to counterterrorism-cooperation with the West, on the one hand, and Russia and China on the other-is evolving toward a closer interaction with their larger neighbors in the region. The Central Asian states face no criticism from China and Russia regarding their repressive methods in dealing with opposition, and are disturbed by Western pressure to improve their human rights situation. States in the region have also been disappointed with the level of Western economic assistance, including in the area of counterterrorism.

\section{Russia and CSTO}

The Central Asian states consider Russia to be their closest partner in dealing with religious extremism, and therefore treat the Russia-led Collective Security Treaty Organization (CSTO) as the main multilateral vehicle of counterterrorism cooperation. Kyrgyzstan hosts a Commonwealth of Independent States (CIS) counterterrorism center in its capital, Bishkek, as well as a Russian Air Force base in Kant. After the Andijan uprising, Uzbekistan rejoined the CSTO. The CSTO has set up rapid-deployment forces in the region and conducts annual counterterrorism exercises. The Rubezh-2006 CSTO military exercises were held in August 2006 in Kazakhstan's Mangistau province. The exercises, which were intended to test the CSTO's collective rapid-deployment force, involved 2,500 personnel, more than 60 armored vehicles, 50 artillery pieces and mortars, 40 aircraft and helicopters, and 14 warships and support vessels. The exercises centered on an operation to resist attempts by radical Islamist groups to establish an Islamic fundamentalist state. The scenario of the exercise was quite telling: "taking advantage of the local population's resentment over the results of a presidential election, terrorist and extremist organizations seize power in a Central Asian state and a neighboring nation's border districts in an attempt to create a caliphate and enlarge its territory by invading a neighboring country. ... The Kazakh authorities then ask the CSTO to provide military assistance to defend the country's sovereignty."23

22 Roger McDermott, “Kazakhstan’s Future Counter-Terrorist Agenda,” Eurasia Daily Monitor 1:115 (28 October 2004); available at http://jamestown.org/edm/article.php?volume_id= 401\&issue_id=3122\&article_id=2368757.

23 Interfax News Agency, 28 August 2006; summary available at www.hri.org/news/balkans/ rferl/2006/06-08-22.rferl.html\#06. 
During his visit to the Kant base in September 2006, Russia's Defense Minister Sergey Ivanov emphasized Russia's long-term interest in the base. According to Ivanov, Russia will invest several billions of rubles in the Kant air base in the next few years. The base is important first of all as an outpost of CIS antiterrorist forces in the region. Planes that take off from Kant can cover all of Central Asia as far as Afghanistan without refueling. Given the current conditions, large groups of narcotics traffickers and terrorists can be tracked and eliminated only with the help of aviation. A military exercise scheduled to be staged next year will practice precisely these tasks, the Russian Defense Minister said. ${ }^{24}$

\section{China and SCO}

The Central Asian states, excluding Turkmenistan, are also involved in the expanding anti-terrorist activities of the Shanghai Cooperation Organization (SCO) as well as bilateral anti-terrorist cooperation with China. On 15 June 2001, the SCO adopted the Shanghai Convention on Combating Terrorism, Separatism, and Extremism. At a summit in Astana on 5 July 2005, the heads of the SCO member states approved a plan for fighting terrorism, separatism, and extremism. In the declaration, SCO members pledged not to give refuge to individuals accused or suspected of terrorist, separatist, or extremist activities. ${ }^{25}$ Tajik President Imomali Rakhmonov proposed at a meeting of the CIS Defense Ministers Council in Dushanbe on 24 June 2005 that the Shanghai Cooperation Organization should create rapid-deployment forces. ${ }^{26}$ Rakhmonov said that the SCO needs "strong collective rapid-deployment forces to counter international terrorism and religious extremism."

The SCO's anti-terrorist cooperation is, however, impeded by a number of factors. The Chinese formula of fighting all the "three evils"-terrorism, separatism, and extremism-does not fully resonate with other SCO members' interests. In particular, identifying who exactly is a "separatist" or "extremist" is problematic in many Central Asian states. Russia does not want the SCO to divert Central Asian states from focusing on their close military cooperation within CSTO. Kazakhstan is wary of joint military exercises under the rubric of the SCO, and fears the gradual transformation of the organization into a military grouping. Kazakh officials prefer to emphasize the confidence-building nature of the organization. For its part, Kyrgyzstan apparently turned down a Chinese offer of a military base on its territory. Acting Deputy Prime Minister Madumarov told a press conference on 29 July 2005 in Almaty, Kazakhstan, where he was on an official visit, that Kyrgyzstan does not intend to host a Chinese military base. ${ }^{27}$ According to Madumarov, "The question of deploying a Chinese military base on Kyrgyz territory was raised at a very high level, but Bishkek's position is unambiguous - we are not prepared to turn the country into a military and political staging ground. We have enough strength and means to defend Kyrgyzstan's sovereignty.”

24 Interfax News Agency, 21 September 2006.

25 Kazakhstan Today (5 July 2005).

26 RFE/RL Tajik Service, 25 June 2005.

27 Kazakhstan Today (1 August 2005). 
In accordance with the charter of the Shanghai Cooperation Organization and the SCO Convention on Fighting Terrorism, Separatism, and Extremism of 15 June 2001, the Executive Committee of the Regional Anti-Terrorist Structure of the Shanghai Organization Cooperation (RATS SCO) started functioning on 1 January 2004 in Tashkent. RATS spent most of 2004 and 2005 elaborating the legal and normative basis of the SCO's cooperation in fighting terrorism, separatism, and extremism. It has compiled a list of organizations to be banned in the SCO states, as well as a list of individuals sought for or suspected of terrorist, extremist, and separatist activities. It is also working to create a database to collect and exchange relevant information. RATS has developed a plan for joint anti-terrorist exercises among SCO member states. The Center has encountered a number of difficulties too, however. Its location in Tashkent and the fact that an Uzbek general is in charge of it at the moment have colored the activities of the Center, and have led to some misunderstandings and problems. ${ }^{28}$

Kazakhstan and China held a two-stage Chinese-Kazakh counterterrorism exercise in China's Xinjiang Uighur Autonomous Region in August 2006. The second phase of the exercise, which followed a first phase in Kazakhstan, involved 700 policemen and 100 observers from the Shanghai Cooperation Organization (SCO). According to Vyacheslav Kasimov, head of the SCO's Regional Anti-Terrorist Structure, the exercise demonstrated regional leaders' commitment to fighting the "three evils" of separatism, terrorism, and extremism. ${ }^{29}$ In October 2006, representatives of Kazakhstan's Eastern Kazakhstan Province and China's Xinjiang Uighur Autonomous Region (XUAR) signed an accord on police cooperation to fight terrorism and drug trafficking. Eastern Kazakhstan Province Governor Viktor Khrapunov referred to ambitious plans for cross-border security cooperation. ${ }^{30}$ In September 2006, Uzbekistan and China signed a security cooperation protocol in Beijing to be in effect for 2006-07. It includes cooperation on police training as well as in fighting terrorism, narcotics trafficking, and cross-border crime. ${ }^{31}$

\section{The U.S. Role}

The September 11 attacks led the U.S. government to realize that it was crucial to the national interests of the United States to greatly enhance relations with the five Central Asian countries in order to prevent them from becoming harbors for terrorism. The U.S. government has moved to classify various groups in the region as terrorist organizations, making them subject to various sanctions. In September 2000, the U.S. State Department designated the IMU as a Foreign Terrorist Organization, stating that the IMU resorts to terrorism, actively threatens U.S. interests, and attacks American citizens. In August 2002, the United States announced that it was freezing any U.S. assets of the East Turkestan Islamic Movement (ETIM), since the group had committed numerous terrorist acts in China and elsewhere and posed a threat to U.S. interests and

28 Kazkhinform (9 February 2005).

29 Xinhua News Agency, 26 August 2006.

30 Interfax-Kazakhstan News Agency, 12 October 2006.

31 Xinhua News Agency, 6 September 2006. 
citizens. In September 2002, the United States, China, and other nations asked the United Nations to add ETIM to its terrorism list.

On the other hand, the United States has not yet classified Hizb ut-Tahrir as a terrorist group. According to the State Department's report Patterns of Global Terrorism 2001, "despite [Eurasian] regional governments' claims, the United States has not found clear links between Hizb ut-Tahrir and terrorist activities." Reflecting this view, U.S. officials have criticized Central Asian governments for imprisoning HT members who are not proven to be actively engaged in terrorist activities, and for imprisoning other political and religious dissidents under false accusations that they are HT members. According to a November 2002 State Department fact sheet, HT has not advocated the violent overthrow of Central Asian governments, so the United States has not designated it as a Foreign Terrorist Organization. The State Department is monitoring HT because it has "clearly incite[d] violence" since 11 September 2001, such as praising Palestinian suicide attacks against Israel, denouncing the basing of U.S.-led coalition forces in Central Asia, and calling for jihad against the United States and the United Kingdom. Nonetheless, the State Department has urged the Central Asian governments to "prosecute their citizens for illegal acts, not for their beliefs.",32

The current U.S. military cooperation with Central Asian states is facing serious challenges, however, due to an angry reaction in Uzbekistan to Western criticism of its handling of the events in Andijan, as well as China and Russia's growing concern about the U.S.'s alleged role in sponsoring “orange revolutions” in Central Asia. The Central Asian political elites have also become suspicious that the United States has been involved in regime changes and social unrest in the post-Soviet region. ${ }^{33}$ In the SCO summit's final declaration on 5 July 2005, the Organization asked the forces in the U.S.-led coalition in Afghanistan to clarify a timeframe for withdrawal from U.S. bases in Uzbekistan and Kyrgyzstan. Soon after, the Uzbek authorities asked the United States to pull all military forces out of the Karshi-Khanabad air base.

Unlike Uzbekistan, Kyrgyzstan has agreed that the U.S. air base can remain there as long as it is needed. Kyrgyz President Kurmanbek Bakiev reiterated this approach in a recent interview with the Russian television channel Vesti-24. He stated that the U.S. air base in Kyrgyzstan will remain until "the situation in Afghanistan is normalized." "Afghanistan is a hotbed of both international terrorism and of drugs," Bakiev said. "It is a real evil. It poses a serious problem, not only to Kyrgyzstan, but to the entire Central Asian region. For this reason, we cooperate [and decided] to host the [U.S.] military base. It has precisely this kind of purpose, a local one: [stabilizing] the situation in Afghanistan., 34

Despite these reassuring comments, there is skepticism among Central Asia experts that the Kyrgyz government is treating the United States more like a source of revenue

32 Washington Post (27 December 2004), A4.

33 Gulnoza Saidazimova, “Five Years After 9/11: Crackdowns Loom Behind Central Asia's War On Terror,” RFE/RL (8 September 2006); available at www.rferl.org/featuresarticle/ 2006/09/23b8c124-00f0-4ee5-b694-bcfb2772a5e9.html.

34 ITAR-TASS News Agency, 30 August 2006. 
(through increased rental fees for the use of the Manas base facility) rather than a genuine partner in combating Islamic radicalism. The 6 December 2006 incident at the Manas air base that culminated in the fatal shooting of a Kyrgyz citizen by a U.S. serviceman has posed an additional challenge to U.S.-Kyrgyz military relations. Kyrgyzstan's parliament passed a resolution on 15 December 2006 calling for a broad review of the U.S. military presence in the country. The resolution urges the Kyrgyz government to review the 2001 Kyrgyz-U.S. agreement on the status of U.S. forces in Kyrgyzstan, request the handover of the U.S. serviceman involved in the incident to Kyrgyz law enforcement authorities, and review the "expediency of the continued presence of Manas Air Base in Kyrgyzstan.”35

According to Dosym Satpaev, who heads an Almaty-based think tank called Risk Assessment Group, the Kyrgyz government is also facing pressure from Uzbekistan, and has therefore lately stepped up its cooperation against what both governments define as terrorists and religious extremists. Satpaev believes that, after 9/11, the Central Asian governments had certain expectations from their cooperation with Washington. They hoped that increased U.S. engagement in the region would help provide better regional security, but they have been somewhat disappointed, as the region continues to face threats and challenges similar to the ones it did five years ago. ${ }^{36}$

\section{Conclusion and Recommendations}

It is quite clear that the United States' security cooperation with Central Asian states has reached a critical stage and needs to be seriously reassessed. It is becoming harder and harder for the United States to continue balancing its counterterrorism and human rights agendas in its relations with Central Asian states without seriously undermining one or the other cause.

U.S. objectives are jeopardized not only by the authoritarian parties of radical Islamist revolution such as Hizb ut-Tahrir, but also by the authoritarian nature of these Central Asian regimes themselves-with their rampant corruption, declining living standards, poor delivery of public goods and services, and stagnant or declining economic growth rates. By governing so poorly, and being intolerant and undemocratic to an alarming degree, these regimes are inadvertently helping to breed religious extremism. The challenge remains to determine how the U.S. can support secular and moderate Islamic regimes and movements, foster tolerance, and promote freedom of expression and freedom of religion without being identified too closely with the repressive actions of Central Asian regimes.

Some, if not most, of these tasks can not be fulfilled in the Central Asian region alone, separate from a consistent and efficient global anti-terrorist campaign. At the same time, the global campaign has to be enhanced by adequate regional efforts. There is no evidence of the United States seriously considering anti-terrorism cooperation with China and Russia in Central Asia. If the three nations can find a common lan-

35 RFE/RL Newsline (19 December 2006).

36 Interfax-Kazakhstan News Agency, 10 September 2006. 
guage on nuclear developments in North Korea, despite their differences of opinion on the North Korean regime, why is not an anti-terrorist forum possible in Central Asia? It is not practical for the United States to continue dismissing or ignoring the Shanghai Cooperation Organization, which is becoming increasingly active in anti-terrorism activities in the region. The United States needs to establish some sort of a dialogue with the SCO as well as the CSTO, and should openly recognize the constructive elements in their work.

The United States also needs to clarify the role of its basing facilities in the Central Asian states. Linking their operation to the campaign in Afghanistan only and, at the same time, implying a certain broader geopolitical context for their existence discourages the Central Asian states from considering the United States as a key partner in dealing with their own radical Islamist movements. Parallel to the establishment of constructive relations with the SCO and CSTO, the United States should make better use of the basing facilities for training regional anti-terrorist forces.

NATO should also explore expanding relations with the SCO. According to Ariel Cohen, for example, options for cooperative efforts may go beyond the existing NATO-Russia Council and the Partnership for Peace, of which most Central Asian states are members. NATO members have a degree of cohesion and unity of values that is not yet present among the SCO member and observer states. Equally important, the SCO is a relatively small organization, still in its infancy, with an operating budget less than USD 30 million and a staff of only a few dozen people. NATO-being larger, stronger, and more experienced in transnational security issues - can engage the SCO in discussions of the strategic issues facing the region, and can help develop paths for cooperation along the lines of Partnership for Peace. ${ }^{37}$

37 Ariel Cohen, "What To Do About The Shanghai Cooperation Organization's Rising Influence,” Eurasia Insight (21 September 2006); available at www.eurasianet.org/departments/ insight/articles/eav092106.shtml. 


\section{Bibliography}

Cohen, Ariel. "What To Do About The Shanghai Cooperation Organization's Rising Influence." Eurasia Insight (2006).

Khamidov, Alisher, and Alisher Saipov. "Islamic Radical Group Bides Time on the Sidelines of Kyrgyzstan's Revolution." Eurasia Insight (2005).

Khamidov, Alisher. "Islamic Radical Group Intensifies Underground Activity in Kyrgyzstan." Eurasia Insight (2003).

Laumulin, M. Trends in the Evolution of Extremism in Central Asia. Almaty: Kazakhstan Institute for Strategic Studies, 2003.

Munavvarov, Z. I., and R. J. Krumm. "The Muslim Board and Muslim Community." InState and Religion in Countries with a Muslim Population. Bonn: Friedrich Ebert Stiftung, 2004.

Rotar, Igor. "Demographics, Borders Complicate Anti-Terrorism Efforts in Central Asia."Eurasia Daily Monitor (2004).

Rotar, Igor. "Hizb ut-Tahrir Today." Terrorism Monitor 2, no. 5 (2004).

Saidazimova, Gulnoza. Five Years After 9/11: Crackdowns Loom Behind Central Asia's War On Terror. RFE/RL, 2006.

Syroezhkin, K.L.. Myths and Realities of Ethnic Separatism in China and Security of Central Asia . Almaty: Daikh Press, 2003.

Weir, Fred. "Islamic Gambit in Central Asia." Christian Science Monitor (2006).

Yermukanov, Marat. "Astana Offers Clumsy Explanations for Banning 'Terrorist Organizations'." Eurasia Daily Monitor 1, no. 108 (2004). 